\title{
Effect of Different Doses of Potassium on Growth, Yield Attributing Characters of Rice in Vertisol Soil of Madhya Pradesh, India
}

\author{
Vinod Birla*, M. D. Vyas ${ }^{2}$, Megha Dubey ${ }^{3}$, Usha Waskle ${ }^{3}$ and Basant Kumar Mandre ${ }^{3}$ \\ ${ }^{1}$ College of Agriculture, Sehore, ${ }^{2}$ College of Agriculture, Powerkheda, ${ }^{3}$ FEO, College of \\ Agriculture, Powerkheda, FEO, ZARS, Powerkheda, Hoshangabad, J.N.K.V.V, Jabalpur, \\ Madhya Pradesh, India \\ *Corresponding author
}

\begin{tabular}{|l|}
\hline Ke y w o r d s \\
Potassium, Rice, \\
Available K, \\
Exchangable K \\
\hline Article Info \\
\hline $\begin{array}{l}\text { Accepted: } \\
\text { 20 February 2020 } \\
\text { Available Online: } \\
\text { 10 March 2020 }\end{array}$ \\
\hline
\end{tabular}

\section{A B S T R A C T}

Potassium in soil exists in several forms like solution, exchangeable, non-exchangeable and lattice $\mathrm{K}$. These potassium forms are in equilibrium with each other. However, plant takes up K mostly from exchangeable and solution form. The present study was conducted on farmers' field at Khamkheda (Dist. Bhopal) under the project initiated by Indian Institute of Soil Science (ICAR), Bhopal. The experiment was laid out in a Randomized Block Design (RBD). The entire experimental area at the farmers' field was divided into five sampling blocks representing the replications to reduce soil heterogeneity. Each block was divided into 4 unit plots with raised bunds as per treatments. Thus, the total number of the unit plots was $20(5 \times 4)$. The size of each unit plot was $(59.4 \mathrm{~m} \mathrm{x} 36 \mathrm{~m})$ and the spacing between blocks was $100 \mathrm{~cm}$ and the plant to plant spacing was maintained at $22 \mathrm{~cm}$. The average maximum, and minimum temperature and relative humidity were $32.25,23.26$ and $81.80 \%$ respectively during crop growing period of rice. The treatments detail was $\mathrm{T}_{1}[0$ $\mathrm{kg} \mathrm{K}$ O/ha $\left(\mathrm{K}_{0}\right.$ ], $\mathrm{T}_{2}\left[48 \mathrm{~kg} \mathrm{~K} \mathrm{~K}_{2} \mathrm{O} / \mathrm{ha}\left(\mathrm{K}_{40}\right)\right.$ ], $\mathrm{T}_{3}\left[96 \mathrm{~kg} \mathrm{~K} \mathrm{~K}_{2} \mathrm{O} / \mathrm{ha}\left(\mathrm{K}_{80}\right)\right.$ ] and $\mathrm{T}_{4}=$ Farmers' Practice $\left(\mathrm{K}_{\mathrm{FP}}\right)^{*}$ consists of $\mathrm{N}, \mathrm{P}_{2} \mathrm{O}_{5}$ and $\mathrm{K}_{2} \mathrm{O} @ 104,73(\mathrm{P}=32)$ and $0 \mathrm{~kg} / \mathrm{ha}$, respectively and $\mathrm{Zn} @ 2.1 \mathrm{~kg} / \mathrm{ha}$. In the field experiment the recommended doses of nutrients were $\mathrm{N}$ @120 kg/ha, $\mathrm{P}_{2} \mathrm{O}_{5} @ 60 \mathrm{~kg} / \mathrm{ha}(\mathrm{P}=26)$ and $\mathrm{Zn} @ 2.5 \mathrm{~kg} / \mathrm{ha}$. The treatment $\mathrm{T}_{3}(96 \mathrm{~kg}$ $\mathrm{K}_{2} \mathrm{O} /$ ha i.e. $\left.\mathrm{K}_{80}\right)$ resulted in maximum plant height $(92.8 \mathrm{~cm})$, number of tillers per meter (198.6), number of leaves per plant (59.4), number of panicles (195.6), length of panicle $(30.2 \mathrm{~cm})$, weight of panicle $(5.04 \mathrm{~g})$, number of grains/panicle $(251.2)$, filled grains/panicle (233.2), unfilled grains /panicle (18.0), test weight (22.05 g), grain yield $(5784 \mathrm{~kg} / \mathrm{ha})$, stover yield (6374 kg/ha), harvest index (47.72), available nitrogen, phosphorous and potash in soil $(222.54,31.58,330.6 \mathrm{~kg} / \mathrm{ha})$. The nutrient content in grain and stover was also increased as $1.2,0.21,0.15$ per cent NPK content in rice grain and $0.28,0.05,2.23$ percent NPK in rice stover. The water soluble potash (7.80), exchangeable potash (139.8), available potash (147.6) and non exchangeable potash 540.83.The treatment $\mathrm{T}_{3}\left(96 \mathrm{~kg} \mathrm{~K} 2 \mathrm{O} / \mathrm{ha}\right.$ i.e. $\left.\mathrm{K}_{80}\right)$ has resulted in reduced cost of cultivation of Rs 39684, gross monetary return Rs 104146, net monetary return Rs 64462 and benefit cost ratio of 2.62 as compared to all other treatments. 


\section{Introduction}

Rice (Oryza sativa L.) has been cultivated since more than 9000 years ago. It is an important food for half of the world population providing $20 \%$ of calorific content. Potassium deficiency was observed in the soils of 84 villages and crops grown in farmers' fields. Deficiency was observed in groundnut, cluster bean, cotton, banana, upland rice, sunflower, maize and other crops on various soils including red soils, sandy light textured soils, degraded lands and shallow black soils (Srinivasarao et al., 1999). Vertisols are predominant soil type occupying $24 \%$ area in our country (Dudal, 1965), However, these soils are now facing fatigue in terms of potassium status and response (Singh et al., 2002; Singh and Wanjari, 2012). Potassium (K) plays vital role in plant nutrition and helps to enhance growth and development of plant. It is one of the essential nutrients required in large quantity by the plants. In our country, it is generally applied to the soil in quantity less than uptake by crop. Hence, Indian soils are now experiencing negative potassium balance to the tune of 10-12 million tons of nutrients in which $\mathrm{K}$ contributes to around $80 \%$. These circumstances are resulting to $\mathrm{K}$ depletion and many soils including Vertisols are responding to $\mathrm{K}$ application. Even though Vertisols are considered to be rich in $\mathrm{K}$ status but due to larger removal of $\mathrm{K}$ from soils than applied, there are reports that soils are at present showing response to applied $\mathrm{K}$. In rice also it is important for boosting the crop yield..

Supply of K from non-exchangeable to exchangeable form determines its response by crop. According to Singh et al., (2002) there was decline in $\mathrm{K}$ release in Vertisol due to continuous cropping in Vertisols whereas application of nutrient resulted increase in cumulative $K$. They also reported that conjunctive use of fertilizer and manure
(FYM or Green manure) resulted in increase in $\mathrm{K}$ release from non-exchangeable $\mathrm{K}$ (Singh et al., 2002). Therefore, it is necessary to study the release pattern of $\mathrm{K}$ in soil to understand its response in different crops and soils. From the data generated from long term fertilizer experiments (LTFE) it has been learnt that crops are responding to applied $\mathrm{K}$ in-spite of high content of $\mathrm{K}$ in Vertisols (Singh and Wanjari, 2012). In soybean-wheat system in Verisols of Jabalpur indicated response to $\mathrm{K}$ in wheat after twenty years of cultivation, whereas in soybean response to applied K was noted after thirty years (Dwivedi et al., 2007 and Singh et al., 2012). A considerable response was noted to potassium by sorghum in Vertisols at Akola also. Therefore, the response of crop to applied $\mathrm{K}$ in spite of high $\mathrm{K}$ status is due to slow release of $\mathrm{K}$ from non-exchangeable form as plant requirement is not met altogether by solution and exchangeable $\mathrm{K}$.

\section{Materials and Methods}

The present study was conducted on farmers' field at Khamkheda (Dist. Bhopal) under the project initiated by Indian Institute of Soil Science (ICAR), Bhopal. The experiment was laid out in a Randomized Block Design (RBD). The entire experimental area at the farmers' field was divided into five sampling blocks representing the replications to reduce soil heterogeneity. Each block was divided into 4 unit plots with raised bunds as per treatments. Thus, the total number of the unit plots was $20(5 \times 4)$. The size of each unit plot was $(59.4 \mathrm{~m} \mathrm{x} 36 \mathrm{~m})$ and the spacing between blocks was $100 \mathrm{~cm}$ and the plant to plant spacing was maintained at $22 \mathrm{~cm}$. The average maximum, and minimum temperature and relative humidity were $32.25,23.26$ and $81.80 \%$ respectively during crop growing period of rice. Total decennial annual rainfall of this area is $1146 \mathrm{~mm}$ (average of last 10 years). December and January are the coldest 
months of winter. Summer season commences in the second fortnight of February and ends in the middle of June. April and May are the hottest months of summer. The average of minimum and maximum temperature during the crop growth period of rice ranged between $14.96^{\circ} \mathrm{C}$ to $39.40^{\circ} \mathrm{C}$ during 2016-17. The range of maximum and minimum temperature was $19.97^{\circ} \mathrm{C}$ to $39.40^{\circ} \mathrm{C}$ and $9.92^{\circ} \mathrm{C}$ to $28.49^{\circ} \mathrm{C}$, respectively. Similarly, range of other weather parameters like relative humidity, rainfall and number of rainy days was between 61.00 to $92.57 \%$, 0 to $323 \mathrm{~mm}$ and 0 to 7 days, respectively during 2016-17. The soil of the experimental area is classified as "Vertisol" based on US classification of soil. It has medium to deep depth and black in colour. It has ability to swell after wetting and shrink after drying. The workability of the soil when wet is very less and agricultural operations damage the structure of soil.

The variety Pusa Basmati 1 (PB 1) was used in the experiment with the seed rate of 20 $\mathrm{kg} / \mathrm{ha}$. Pusa Basmati-1 is a semi dwarf plant which consists of almost all the features of traditional basmati including alkali content, grain elongation and rich fragrance. It is also known as todal because there are awns present in its flower. Pusa Basmati-1 rice is one of the most demanded rice species all over the world under the seeds Act of 1966 PB-1 was declared as a variety of basmati. It is a semi dwarf and photoperiod insensitive variety. It attains height of about $100 \mathrm{~cm}$ and matures in about 140 days after seeding. It performs best under high fertility conditions. It possesses extra-long slender grains with mild aroma which is non sticky and soft to eat upon cooking. Like semi dwarf varieties of rice, Basmati varieties require prolonged sunshine, high humidity and assured water supply. Basmati varieties with superior cooking and eating characteristics can be produced if the crop matures in relatively cooler temperature. The high temperature during grain filling period reduce the cooking and eating quality feature of basmati rice like kernel elongation and non-stickiness of cooked rice. The treatments detail is $\mathrm{T}_{1}[0 \mathrm{~kg}$ $\mathrm{K}_{2} \mathrm{O} / \mathrm{ha}\left(\mathrm{K}_{0}\right)$ ], $\mathrm{T}_{2}$ [48 $\left.\mathrm{kg} \mathrm{K}_{2} \mathrm{O} / \mathrm{ha}\left(\mathrm{K}_{40}\right)\right], \mathrm{T}_{3}$ [96 $\left.\mathrm{kg} \mathrm{K}_{2} \mathrm{O} / \mathrm{ha}\left(\mathrm{K}_{80}\right)\right]$ and $\mathrm{T}_{4}=$ Farmers' Practice $\left(\mathrm{K}_{\mathrm{FP}}\right)^{* *}$ Farmers' Practice treatment consists of $\mathrm{N}, \mathrm{P}_{2} \mathrm{O}_{5}$ and $\mathrm{K}_{2} \mathrm{O} @ 104,73(\mathrm{P}=32)$ and 0 $\mathrm{kg} / \mathrm{ha}$, respectively and Zn @ $2.1 \mathrm{~kg} / \mathrm{ha}$. In the field experiment the recommended doses of nutrients were $\mathrm{N} @ 120 \mathrm{~kg} / \mathrm{ha}, \mathrm{P}_{2} \mathrm{O}_{5} @ 60$ $\mathrm{kg} / \mathrm{ha}(\mathrm{P}=26)$ and $\mathrm{Zn} @ 2.5 \mathrm{~kg} / \mathrm{ha}$.

\section{Method of Nursery management}

The field was tilled with the help of tractor driven tyne cultivator followed by two harrowings with disc harrow to prepare a well pulverized seed bed for raising of rice nursery. The stubbles, stones and weeds were removed to obtain the clean seedbed. After this, 3 separate nursery beds each of $5.0 \mathrm{~m} \mathrm{x}$ $1.5 \mathrm{~m}$ dimension were prepared. The nursery beds were raised to a height of $20 \mathrm{~cm}$ by spreading the loose soils on surface of bed, which were collected from both the sides of nursery beds in length direction. The channel with $30 \mathrm{~cm}$ width and $10 \mathrm{~cm}$ depth was dugout on both sides of the nursery beds. The soils of the channels were used for raising the nursery beds and these channels were helpful for irrigation and drainage as and when needed. After this, $25 \mathrm{~kg}$ FYM/bed was uniformly spread on the surface of nursery beds and then, it was well mixed in soil. Healthy seeds of Pusa Basmati-1 were treated with Thirum @ $3 \mathrm{~g} / \mathrm{kg}$ of seeds before sowing in nursery beds on $29^{\text {th }}$ June and $12^{\text {th }}$ July in 2016 to obtain the seedlings of desirable age for transplanting as per treatments. Seeds of this variety were evenly sown separately on seed beds in rows $10 \mathrm{~cm}$ apart and well covered with mixture of dried FYM and soil. A light irrigation was given immediately after sowing of seeds for germination. Thereafter, 
frequent irrigations were given as and when needed. Proper weed management and after care were taken into consideration to raise the seedlings of desirable age for transplanting as per treatments. Bird watching, check drainage and irrigation are necessary practices to get a proper seedling in nursery. Hand weeding was done.

\section{Method of field preparation}

After completion of first flush of weeds in field by receiving the pre-monsoon rains, the field was tilled with disc harrow. The final seedbed for transplanting of seedlings and direct seeding of sprouted seeds was prepared by puddling of soil with the help of tractor driven rotavator. For puddling operation, rainwater was impounded in the field with the support of dyke, provided all around. In case of transplanted rice, the field was tilled by tractor drawn cultivator, cross-wise and rain water was impounded 2-3 days before puddling. The field was puddled by tractor drawn puddler, cross-wise, and finally the field was leveled by leveler a day before the transplanting operation. After this, layout of the field was made to allocate the various treatments.

Land preparation was started on 10 May, 2016. The land was prepared thoroughly by ploughing and cross ploughing with a power tiller. Every ploughing was followed by laddering to have a good tilth. Weeds and stubbles of the previous crop were collected and removed from the plot. After uniform leveling, the plots were laid out as per treatments and design of the experiment.

Weeds like wild rice (Echinochloa colonum), Barnyard grass (Echinocloa crusgalli), Motha (Cyperus rotundus), false daisy (Eclipta alba), and Bermuda grass (Cynodon dactylon) were predominant in the field after transplanting. These weeds were kept under control by hand weeding at the stage of 27-30 days after transplanting while second weeding was done after 60 DAT.

Rice stem borer (Scirpophaga incertulas), brown plant hopper (Nilaparvata lugens), white backed plant hopper (Sogatella furcifera), green leaf hopper (Nephotettex nigropictus), rice thrips (Stenochaetothrips biformis) etc appeared at flowering while rice gundhy bug (Leptocorisa acuta) attack was seen at milking stage. To control stem borer in rice a chemical i.e. Cartap hydrochloride was applied in the soil. The spray of Betacyfluthrin 8.5\% w/w + Imidacloprid 19.8\%w/w@1 ml/litre of water was sprayed at both the stages, respectively.

The harvesting of the experimental plots was done on 25/10/2016. To avoid the border effect, border rows were first harvested before the harvest of net plot. The produce of each plot was tied in bundles and weighed with the help of balance. The produce from each plot was recorded and yield per hectare (ha) was worked out.

\section{Method of analysis of different forms of $K$}

\section{Water soluble $\mathrm{K}$}

It was estimated in 1:5, soil, water ratio suspension as described by Black (1965).

\section{Exchangeable $\mathrm{K}$}

It was determined by Flame photometer in the extract of $1 \mathrm{~N}$ neutral ammonium acetate solution in 1:5 soil: extract ratio as described by Black (1965).

\section{Non-exchangeable $K$}

$1 \mathrm{~N}$ boiling $\mathrm{HNO}_{3}$ extractable potassium was estimated flame photometerically in 1:10, soil: acid suspension boiled for 10 minutes as described by Black (1965). 


\section{Total K}

Total potassium was estimated flame photometerically by digesting soil with hydrofluoric (48\%) and perchloric (70-72\%) acid in platinum crucible by the method outlined by Black (1965).

\section{Lattice K}

It was estimated by difference between total $\mathrm{K}$ and sum of water soluble, exchangeable and non-exchangeable potassium.

Analysis Variance (ANOVA) for randomized block design was worked out and the significance of treatments were tested to draw valid conclusions as described by Gomez and Gomez (1984).

\section{Results and Discussion}

Application of different doses of potassium were effective to maximize the yield and yield components viz., plant height, number of tillers, number of leaves, number of panicle, its length and weight, number of grains per panicle (filled and unfilled), test weight (1000-grain), grain and stover yield of rice (Pusa Basmati-1). The application of $80 \mathrm{~kg}$ $\mathrm{K} / \mathrm{ha}\left(96 \mathrm{~kg} \mathrm{~K}_{2} \mathrm{O} / \mathrm{ha}\right.$ i.e. $\mathrm{K}_{80}$ ) along with recommended doses of $\mathrm{N}$ and $\mathrm{P}$ fertilizer are the balance sources of nutrients and it has produced the highest grain and straw yield of Pusa Basmati-1. Moreover, the yield was considerably higher as compared to that obtained from the no application of the recommended doses of $\mathrm{K}$ fertilizer as give $\mathrm{I}$ table 1 (a) and (b). The data on plant population indicated that there was no significant effect of potassium application on plant population in rice grown on Vertisols. This could be due to planting of almost equal number of rice seedlings during transplanting. Plant height of Pusa Basmati-1 was significantly affected due to different treatments. All the treatments significantly increased the plant height over farmers' practice. The maximum plant height was recorded in the treatment $\mathrm{T}_{3}\left(96 \mathrm{~kg} \mathrm{~K}_{2} \mathrm{O} / \mathrm{ha}\right.$ i.e. $\mathrm{K}_{80}$ ) which was, however, identical to the treatment $\mathrm{T}_{4}$ (Farmers' practice) and $\mathrm{T}_{2}$ (48 $\mathrm{kg} \mathrm{K}_{2} \mathrm{O} / \mathrm{ha}$ or $\mathrm{K}_{40}$ ). This observation indicated that $\mathrm{K}$ has increased plant height as it enhances transportation of $\mathrm{N}, \mathrm{P}$ and other nutrients. The results clearly showed that application of K- fertilizer increased the plant height which was comparable to that of recommended fertilizer dose. Bahmaniar et al., (2007) found that plant height increased significantly due to $\mathrm{K}$ application. Similar results were also observed by Biswas et al., (2001), Mukherjee and Sen (2005) and Sahu et al., (2015). The maximum number of tillers $/ \mathrm{m}^{2}$ (198) was found in the treatment $\mathrm{T}_{3}$ ( $96 \mathrm{~kg} \mathrm{~K}_{2} \mathrm{O} /$ ha i.e. $\mathrm{K}_{80}$ ) which was statistically at par with $\mathrm{T}_{2}\left(48 \mathrm{~kg} \mathrm{~K}_{2} \mathrm{O} / \mathrm{ha}\right.$ or $\left.\mathrm{K}_{40}\right)$ with 196. It indicated that $\mathrm{K}$ application at higher rates over control has significant effect on number of tillers $/ \mathrm{m}^{2}$. It illustrates that $\mathrm{K}$ enhances nutrient use efficiency of other nutrients like N, P and S. Thakur et al., (1993) reported that an increase in potassium level up to $66 \mathrm{~kg} \mathrm{~K} \mathrm{ha}{ }^{-1}$ increased the number of tillers $/ \mathrm{m}^{2}$. Similar result was also reported by Meena et al., (2003) and Tabar et al., (2012). The number of leaves at different growth stages of rice (30, 60 and at harvest) are being influenced by graded doses of $\mathrm{K}$ application. It is quite clear from the data that number of leaves increased with the advancement in growth stages of rice and a very fast growth was in between 30 to 60 DAT and thereafter, a slight decline. It is quite obvious that higher number of leaves led to higher transport of photosynthesis that result in higher grain yield as give in Table 1(a).

Number of panicles is one of the prime yield attributes which contributes to the grain yield of rice. The treatment $\mathrm{T}_{3}$ resulted in significantly higher number of effective panicle $\left(195\right.$ per $\left.\mathrm{m}^{2}\right)$ over the treatment $\mathrm{T}_{4}$ and other treatments as well. On the contrary, 
the minimum number of effective panicle (188.2 per $\mathrm{m}^{2}$ ) were obtained with farmers' practice followed by $\mathrm{T}_{1}\left(0 \mathrm{~kg} \quad \mathrm{~K}_{2} \mathrm{O} / \mathrm{ha}\right)$. Similar finding was recorded by Sahu et al., (2015). Panicle length and weight are also equally important yield attributing characters. The application of $\mathrm{K}$ - fertilizer at different levels has significantly increased the panicle length but not influence the panicle weight of rice cv Pusa Basmati-1. The highest panicle length of $30.2 \mathrm{~cm}$ was found in treatment $\mathrm{T}_{3}$ (96 $\mathrm{kg} \mathrm{K}_{2} \mathrm{O} / \mathrm{ha}$ i.e. $\mathrm{K}_{80}$ ). The values for panicle length of all the treatments were higher than that of the farmers' practice. The number of filled grains and test weight are the important yield attributes which reflects in grain yield of rice. The number of filled grains per panicle and test weight of Pusa Basmati-1 showed a significant increase due to the application of different $\mathrm{K}$ levels. The highest number of grains per panicle was obtained with $\mathrm{T}_{3}\left(96 \mathrm{~kg} \mathrm{~K}_{2} \mathrm{O} /\right.$ ha i.e. $\left.\mathrm{K}_{80}\right)$ followed by $\mathrm{T}_{2}\left(48 \mathrm{~kg} \mathrm{~K} 2 \mathrm{O} / \mathrm{ha}\right.$ or $\left.\mathrm{K}_{40}\right), \mathrm{T}_{1}(0$ $\mathrm{kg} \mathrm{K}_{2} \mathrm{O} / \mathrm{ha}$ ) and $\mathrm{T}_{4}$ (Farmers' practice). The results suggest that potassium exerted significant role on the formation of grains of rice and filled grains in particular. It has been reported by several researchers that application of potassium increased percent grains (Kaliha et al., 1995; Mitra et al., 2001; and Krishnappa et al., (2006). However, on the contrary, Bahmaniar et al., (2007) found that application of potassium has no significant effect on test weight as given in Table 1 (b). Potassium is one of three primary nutrients required by crops to complete their life cycle and produce food (Majumdar et al., 2012). In true sense it carries the meaning that potassium plays key role in enhancing the yield attributes as it has been seen in previous sections. It ultimately reflected in significant increase in grain yield of rice cv Pusa Basmati-1 due to $\mathrm{K}$ application. The grain yield obtained due to graded doses of $\mathrm{K}$ was in ascending order of $T_{3}>T_{2}>T_{1}>T_{4}$. The highest grain yield with $\mathrm{T}_{3}\left(96 \mathrm{~kg} \mathrm{~K} \mathrm{~K}_{2} \mathrm{O} /\right.$ ha i.e.
$\mathrm{K}_{80}$ ) followed by $\mathrm{T}_{2}\left(48 \mathrm{~kg} \mathrm{~K}_{2} \mathrm{O} / \mathrm{ha}\right.$ or $\left.\mathrm{K}_{40}\right)$ which was higher by $5.68 \%$ and $3.96 \%$, respectively over $\mathrm{T}_{1}\left(0 \mathrm{~kg} \quad \mathrm{~K}_{2} \mathrm{O} / \mathrm{ha}\right)$. This implies that potassium has significant role on grain yield of rice. Saha et al., (2007) observed that application of potassium resulted in higher production of rice yield. Krishnappa et al., (2006) reported that increasing potassium rates increased rice yields. Similar results were also observed by Mathad et al., (2002), Biswas et al., (2001), Singh et al., (1999). The straw yield of Pusa Basmati-1 was also significantly influenced due to $\mathrm{K}$ doses and recorded ranked in the order of $T_{3}>T_{2}>T_{1}>T_{4}$. Rice plants treated with fertilizers encouraged rapid vegetative growth leading to the production of higher straw yield. The results revealed that the application of higher dose of potassium exerted pronounced effect in producing higher straw yield of rice. Singh and Singh (2000) reported that the highest straw yield of rice was obtained with the application of $96 \mathrm{~kg}$ $\mathrm{K}_{2} \mathrm{O} /$ ha i.e. $\mathrm{K}_{80}$. Similar result was also observed by Saha et al., (2007), Bahmaniar et al., (2007), Razzaque et al., (1990). There was no significant difference in harvest index with graded doses of $\mathrm{K}$ applied in rice probably due to proportionate deviation in the grain and straw biomass as given in Table 2.Nitrogen being an integral part of many compounds, absorbed by plant is readily converted into amino acid and proteins. In the post-harvest soil samples, available $\mathrm{N}$ ranged from 218 to $222 \mathrm{~kg} / \mathrm{ha}$ indicating that there was slight decline (compared to initial status) in the available nitrogen after the harvest of the crop in spite of recommended dose of $\mathrm{N}$. This signifies that to meet the nutritional demand of the crop the nitrogen has been taken up by the plant to produce higher yield. Similarly, phosphorous is important in plant nutrition as it is a component of ADP and ATP involved in the most significant energy transformation in plants through both respiration and photosynthesis, contains a 
high energy phosphate group that drives most biochemical processes requiring energy, essential component of DNA and RNA needed for protein synthesis. It was observed that available $\mathrm{P}$ status in soil was almost similar and stable compared to initial status even though recommended dose of $\mathrm{P}$ was applied to rice. It shows that rice (cv Pusa Basmati 1) crop has taken $P$ in balance manner. Similar observation was recorded by Sharma and Subehia (2014). Potassium is a very important nutrient which maintains the water balance in the plant system. The available status of $\mathrm{K}$ has slightly decreased compared to initial values under different treatments. This indicated that there was decline of available $\mathrm{K}$ in both the cases whether potassium was added or not, however, magnitude of difference was less in treatment with higher dose. Singh et al., (2014) also documented that the available K was reported to be $392 \mathrm{~kg} \mathrm{ha}^{-1}$ in treatment where potassium was applied with FYM.

Nitrogen, phosphorus and potassium content in grain of Pusa Basmati-1 was non significantly affected by different treatments except the $\mathrm{N}$ content in grain and $\mathrm{K}$ in straw of Pusa Basmati 1. The $\mathrm{N}$ content in grain was statistically significant which ranges from 0.95 to $1.20 \%$. The potassium content in straw due to different treatments varied from 2.116 to $2.238 \%$. It is observed that $\mathrm{K}$ content in straw was higher than that of grains in all the treatments. It indicates that the recommended fertilizer dose had significant effect on $\mathrm{K}$ content in straw and the increase of the fertilizers from the recommended fertilizer dose affected $\mathrm{K}$ content significantly. The application of recommended fertilizer dose performed better in increasing $\mathrm{K}$ content both in grain and straw of Pusa Basmati-1. Krishnappa et al., (2006) reported that $\mathrm{K}$ application increased $\mathrm{K}$ content in rice as given in Table 3 .

Even though few years back Vertisols has been remarked as rich soils in India, these soils are now experiencing fatigue in terms of $\mathrm{K}$ status and gradually responding to external application of K (Srinivasarao et al., 1999; Singh et al., 2001). The experiment was conducted on farmers' field in these Vertisols with the view to know whether these K-forms changes with the graded doses of applied $\mathrm{K}$ through fertilizers. Status of different forms of $\mathrm{K}$ was studied which ranged from 5.00 to 7.80 $\mathrm{mg} / \mathrm{kg}$ under different blocks with an average value of $6.70 \mathrm{mg} / \mathrm{kg}$. Result on the same line with different soil types have also been reported by Padole and Mahajan (2003) and Chandrasekharao and Krishnamurthy (2007). Exchangeable $\mathrm{K}$ content in soil was found in the range of 115 to $139 \mathrm{mg} / \mathrm{kg}$ under different blocks with an average value of $137 \mathrm{mg} / \mathrm{kg}$. Kaskar et al., (2001) and Padole and Mahajan (2003) also reported that exchangeable $\mathrm{K}$ contributed towards total $\mathrm{K}$, exchangeable as well as variation in labile pool due to potassium fertilization. The water soluble and exchangeable forms of $\mathrm{K}$ collectively called as available $\mathrm{K}$. It showed significant change due to differential doses of $\mathrm{K}$ in soil. The available $\mathrm{K}$ varied from 120.4 to 147.6 indicating medium status as per fertility rating chart. Similarly, trend was observed in case of available as well as non-exchangeable $\mathrm{K}$ (NEK) form. The non-exchangeable K (NEK) ranged from 484 to $540 \mathrm{mg} / \mathrm{kg}$ soil. The highest status of these $\mathrm{K}$ forms was observed in $\mathrm{T}_{3}\left(96 \mathrm{~kg} \mathrm{~K}\right.$ O/ha i.e. $\left.\mathrm{K}_{80}\right)$ followed by $\mathrm{T}_{2}$ (48 $\left.\mathrm{kg} \quad \mathrm{K}_{2} \mathrm{O} / \mathrm{ha}\right), \mathrm{T}_{1}\left(\begin{array}{llll}0 & \mathrm{~kg} & \mathrm{~K}_{2} \mathrm{O} / \mathrm{ha}\end{array}\right)$ and farmers' practice as given in Table 4. Correlation matrix showing relationship between yield of rice $(\mathrm{kg} / \mathrm{ha})$ and potassium forms in Vertisols was obtained with the help of statistical tool. The correlation was find out between five variables namely (i) Yield of rice as dependable variable and (ii) Water soluble K (iii) Exchangeable K (iv) Available $\mathrm{K}$ and (v) Non-exchangeable $\mathrm{K}$ as independent variable. 
Table.1(a) Effect of potassium application on growth parameters

\begin{tabular}{|c|c|c|c|c|c|c|c|c|c|c|}
\hline \multirow[t]{2}{*}{ Treatments } & \multirow{2}{*}{$\begin{array}{c}\text { Plant } \\
\text { population } \\
\left(\mathbf{n o .} / \mathbf{m}^{2}\right)\end{array}$} & \multicolumn{3}{|c|}{ Plant height (cm) } & \multicolumn{3}{|c|}{ No of tillers $/ \mathrm{m}^{2}$} & \multicolumn{3}{|c|}{ Number of leaves (No./plant) } \\
\hline & & 30 DAT & 60 DAT & At harvest & 30 DAT & 60 DAT & At harvest & 30 DAT & 60 DAT & $\begin{array}{c}\text { At } \\
\text { harvest }\end{array}$ \\
\hline $\mathbf{T}_{1}$ & 20.6 & 19.0 & 44.40 & 88.80 & 95.80 & 144. & 191.4 & 18.20 & 61.20 & 56.4 \\
\hline $\mathbf{T}_{2}$ & 21.6 & 20.6 & 49.60 & 92.80 & 96.60 & 161. & 196.4 & 18.20 & 62.80 & 59.0 \\
\hline $\mathbf{T}_{3}$ & 22.6 & 20.0 & 50.20 & 92.80 & 101.2 & 167. & 198.6 & 18.60 & 64.60 & 59.4 \\
\hline $\mathbf{T}_{4}$ & 21.0 & $\begin{array}{c}19.2 \\
n\end{array}$ & 43.20 & 88.60 & 94.80 & 131. & $\begin{array}{c}190.4 \\
n\end{array}$ & 16.00 & 54.60 & 50.2 \\
\hline SEm \pm & 0.78 & 0.28 & 0.50 & 1.30 & 1.12 & 2.16 & 1.10 & 0.34 & 0.55 & 1.10 \\
\hline CD at $5 \%$ & NS & 0.87 & 1.57 & 4.01 & 3.47 & 6.66 & 3.41 & 1.07 & 1.7 & 3.41 \\
\hline
\end{tabular}

$\mathrm{T}_{1}: 0 \mathrm{~kg} \mathrm{~K} \mathrm{~K}_{2} \mathrm{O} / \mathrm{ha}\left(\mathrm{K}_{0}\right), \mathrm{T}_{2}: 48 \mathrm{~kg} \mathrm{~K}_{2} \mathrm{O} / \mathrm{ha}, \mathrm{T}_{3}: 96 \mathrm{~kg} \mathrm{~K}_{2} \mathrm{O} / \mathrm{ha}, \mathrm{T}_{4}$ : Farmers' practice

Table.1(b) Effect of potassium application on growth parameters

\begin{tabular}{|c|c|c|c|c|c|c|c|c|c|}
\hline Treatments & $\begin{array}{c}\text { Days to } \\
50 \% \\
\text { panicle } \\
\text { emergence }\end{array}$ & $\begin{array}{c}\text { Days } \\
\text { taken to } \\
\text { maturity }\end{array}$ & $\begin{array}{c}\text { Number } \\
\text { of panicle } \\
\left(\mathrm{No} / \mathrm{m}^{2}\right)\end{array}$ & $\begin{array}{l}\text { Length } \\
\text { of } \\
\text { panicle } \\
\text { (cm) }\end{array}$ & $\begin{array}{l}\text { Weight } \\
\text { of panicle } \\
\text { (g) }\end{array}$ & $\begin{array}{c}\text { Number of } \\
\text { grains/ } \\
\text { panicle }\end{array}$ & $\begin{array}{c}\text { Filled } \\
\text { grains / } \\
\text { panicle }\end{array}$ & $\begin{array}{l}\text { Unfilled } \\
\text { grains / } \\
\text { panicle }\end{array}$ & $\begin{array}{c}\text { Test weight } \\
\text { (g) }\end{array}$ \\
\hline $\mathbf{T}_{1}$ & 66.8 & 132.0 & 189.60 & 28.8 & 4.76 & 228.6 & 207.0 & 21.60 & 21.01 \\
\hline $\mathbf{T}_{2}$ & 70.2 & 135.2 & 194.00 & 29.0 & 4.84 & 237.0 & 217.4 & 19.60 & 21.58 \\
\hline $\mathbf{T}_{3}$ & 72.0 & 138.4 & 195.60 & 30.2 & 5.04 & 251.2 & 233.2 & 18.00 & 22.05 \\
\hline $\mathbf{T}_{4}$ & 65.6 & 133.6 & 188.20 & 28.4 & 4.75 & 226.4 & 205.8 & 20.60 & 21.14 \\
\hline SEm \pm & 0.54 & 0.38 & 1.65 & 0.38 & 0.24 & 3.36 & 3.76 & 1.56 & 0.10 \\
\hline CD at & 1.71 & 1.19 & 5.10 & 1.19 & NS & 10.38 & 11.58 & NS & 0.32 \\
\hline
\end{tabular}

$\mathrm{T}_{1}: 0 \mathrm{~kg} \mathrm{~K} 2 \mathrm{O} / \mathrm{ha}\left(\mathrm{K}_{0}\right), \mathrm{T}_{2}: 48 \mathrm{~kg} \mathrm{~K}_{2} \mathrm{O} / \mathrm{ha}, \mathrm{T}_{3}: 96 \mathrm{~kg} \mathrm{~K}_{2} \mathrm{O} / \mathrm{ha}, \mathrm{T}_{4}$ : Farmers' practice 
Table.2 Effect of potassium application on grain yield, stover yield, harvest index, available N,P and K in soil

\begin{tabular}{|c|c|c|c|c|c|c|}
\hline $\begin{array}{l}\text { Treatmen } \\
\text { ts }\end{array}$ & $\begin{array}{l}\text { Grain } \\
\text { Yield } \\
\text { (kg/ha) }\end{array}$ & $\begin{array}{c}\text { Stover } \\
\text { Yield } \\
\text { (kg/ha) }\end{array}$ & $\begin{array}{l}\text { Harvest } \\
\text { index }(\%)\end{array}$ & $\begin{array}{l}\text { Available } \mathrm{N} \text { in } \\
\text { soil (kg/hec) }\end{array}$ & $\begin{array}{c}\text { Available } P \\
\text { in soil } \\
(\mathrm{kg} / \mathrm{hec})\end{array}$ & $\begin{array}{c}\text { Available K } \\
\text { in soil (kg/ha) }\end{array}$ \\
\hline $\mathbf{T}_{1}$ & 5473 & 6142 & 46.80 & 218.27 & 30.21 & 277.0 \\
\hline $\mathbf{T}_{2}$ & 5690 & 6327 & 47.28 & 219.52 & 31.59 & 322.0 \\
\hline $\mathbf{T}_{3}$ & 5784 & 6374 & 47.72 & 222.54 & 31.58 & 330.6 \\
\hline $\mathbf{T}_{4}$ & 5072 & 5908 & 46.58 & 220.42 & 30.57 & 269.6 \\
\hline SEm \pm & 49.22 & 69.44 & 1.21 & 2.33 & 0.88 & 0.82 \\
\hline $\begin{array}{l}\text { CD at } \\
5 \%\end{array}$ & 151.65 & 213.95 & NS & NS & NS & 2.55 \\
\hline
\end{tabular}

$\mathrm{T}_{1}: 0 \mathrm{~kg} \mathrm{~K} \mathrm{O}_{2} \mathrm{O} / \mathrm{ha}\left(\mathrm{K}_{0}\right), \mathrm{T}_{2}: 48 \mathrm{~kg} \mathrm{~K} \mathrm{O}_{2} / \mathrm{ha}, \mathrm{T}_{3}: 96 \mathrm{~kg} \mathrm{~K}_{2} \mathrm{O} / \mathrm{ha}, \mathrm{T}_{4}$ : Farmers' practice

Table.3 Effect of potassium application on nutrient content in rice grain and stover

\begin{tabular}{|c|c|c|c|c|c|c|}
\hline \multirow{2}{*}{$\begin{array}{l}\text { Treatmen } \\
\text { ts }\end{array}$} & \multicolumn{3}{|c|}{ Nutrient contents $(\%)$ in rice grain } & \multicolumn{3}{|c|}{ Nutrient contents $(\%)$ in rice stover } \\
\hline & $\mathbf{N}(\%)$ & $\mathbf{P}(\%)$ & $\mathbf{K}(\%)$ & $\mathbf{N}(\%)$ & $\mathbf{P}(\%)$ & $\mathbf{K}()(\%)$ \\
\hline $\mathbf{T}_{1}$ & 1.15 & 0.14 & 0.10 & 0.262 & 0.063 & 2.116 \\
\hline $\mathbf{T}_{2}$ & 1.17 & 0.17 & 0.12 & 0.280 & 0.058 & 2.126 \\
\hline $\mathbf{T}_{3}$ & 1.20 & 0.21 & 0.15 & 0.284 & 0.054 & 2.238 \\
\hline $\mathbf{T}_{4}$ & 0.95 & 0.16 & 0.11 & 0.236 & 0.053 & 2.154 \\
\hline SEm \pm & 0.01 & 0.01 & 0.01 & 0.030 & 0.002 & 0.082 \\
\hline CD at & 0.05 & NS & NS & NS & NS & 0.254 \\
\hline
\end{tabular}

$\mathrm{T}_{1}: 0 \mathrm{~kg} \mathrm{~K} \mathrm{~K}_{2} \mathrm{O} / \mathrm{ha}\left(\mathrm{K}_{0}\right), \mathrm{T}_{2}: 48 \mathrm{~kg} \mathrm{~K} \mathrm{~K}_{2} \mathrm{O} / \mathrm{ha}, \mathrm{T}_{3}: 96 \mathrm{~kg} \mathrm{~K}_{2} \mathrm{O} / \mathrm{ha}, \mathrm{T}_{4}:$ Farmers' practice 
Table.4 Effect of potassium application on different forms of potassium (mg/kg soil) in Vertisols

\begin{tabular}{|l|c|c|c|c|}
\hline Treatments & Water soluble-K & Exchangeable K & Available K & Non-Exchangeable K \\
\hline $\mathbf{T}_{\mathbf{1}}$ & 5.60 & 118.00 & 123.6 & 495.20 \\
\hline $\mathbf{T}_{\mathbf{2}}$ & 6.70 & 137.10 & 143.8 & 516.80 \\
\hline $\mathbf{T}_{\mathbf{3}}$ & 7.80 & 139.80 & 147.6 & 540.83 \\
\hline $\mathbf{T}_{\mathbf{4}}$ & 5.00 & 115.40 & 120.4 & 484.80 \\
\hline $\mathbf{S E m} \pm$ & 0.14 & 0.49 & 0.38 & 1.14 \\
\hline $\mathbf{C D}$ at 5\% & 0.50 & 1.53 & 1.20 & 3.52 \\
\hline
\end{tabular}

$\mathrm{T}_{1}: 0 \mathrm{~kg} \mathrm{~K} \mathrm{~K}_{2} \mathrm{O} / \mathrm{ha}\left(\mathrm{K}_{0}\right), \mathrm{T}_{2}: 48 \mathrm{~kg} \mathrm{~K} \mathrm{O} / \mathrm{ha}, \mathrm{T}_{3}: 96 \mathrm{~kg} \mathrm{~K}_{2} \mathrm{O} / \mathrm{ha}, \mathrm{T}_{4}$ : Farmers' practice

Table.5 Relationship between potassium forms and rice productivity

A) Correlation Matrix

\begin{tabular}{|c|c|c|c|c|c|}
\hline Correlation Matrix & Rice yield (kg/ha) & WSK (mg/kg) & ExK (mg/kg) & $\operatorname{AvK}(\mathrm{mg} / \mathrm{kg})$ & NEK (mg/kg) \\
\hline Rice yield (kg/ha) & 1.000 & & & & \\
\hline WSK (mg/kg) & 0.640 & 1.000 & & & \\
\hline ExK (mg/kg) & 0.824 & 0.829 & 1.000 & & \\
\hline AvK (mg/kg) & 0.819 & 0.860 & 0.998 & 1.000 & \\
\hline NEK (mg/kg) & 0.825 & 0.892 & 0.940 & 0.950 & 1.000 \\
\hline
\end{tabular}

WSK= Water soluble K; ExK= Exchangeable K; AvK=Available K; NEK=Non-Exchangeable 
B) Student T Test

\begin{tabular}{|l|c|c|c|}
\hline Variables Tested & T Value & T Table & Significance at 5\% \\
\hline Yield -WSK & 3.538 & 2.101 & Significant \\
\hline Yield -ExK & 6.171 & 2.101 & Significant \\
\hline Yield -Avk & 6.054 & 2.101 & Significant \\
\hline Yield -NEK & 6.195 & 2.101 & Significant \\
\hline WSK - ExK & 6.294 & 2.101 & Significant \\
\hline WSK -AvK & 7.137 & 2.101 & Significant \\
\hline WSK -NEK & 8.350 & 2.101 & Significant \\
\hline ExK -AvK & 70.466 & 2.101 & Significant \\
\hline ExK -NEK & 11.652 & 2.101 & Significant \\
\hline AvK -NEK & 12.928 & 2.101 & Significant \\
\hline
\end{tabular}

WSK= Water soluble K; ExK=Exchangeable K; AvK=Available K; NEK= Non-Exchangeable K

Table.6 Effect of different treatments on economics

\begin{tabular}{|l|c|c|c|c|}
\hline Treatments & $\begin{array}{c}\text { Total cost of cultivation } \\
\text { (Rs/ha) }\end{array}$ & Gross return (Rs/ha) & Net profit (Rs/ha) & $\begin{array}{c}\text { Benefit : Cost ratio (per Rs } \\
\text { invested) }\end{array}$ \\
\hline $\mathbf{T}_{\mathbf{1}}$ & 36344 & 98879 & 62535 & 2.72 \\
\hline $\mathbf{T}_{\mathbf{2}}$ & 38001 & 102624 & 64623 & 2.70 \\
\hline $\mathbf{T}_{\mathbf{3}}$ & 39684 & 104146 & 64462 & 2.62 \\
\hline $\mathbf{T}_{\mathbf{4}}$ & 42727 & 92282 & 49555 & 2.15 \\
\hline
\end{tabular}

*Minimum Support Price (MSP)= Rs. 1470 per quintal (Govt rate)** $\mathrm{T}_{1}: 0 \mathrm{~kg} \mathrm{~K} \mathrm{~K}_{2} \mathrm{O} / \mathrm{ha}\left(\mathrm{K}_{0}\right), \mathrm{T}_{2}: 48 \mathrm{~kg} \mathrm{~K}_{2} \mathrm{O} / \mathrm{ha}, \mathrm{T}_{3}: 96 \mathrm{~kg} \mathrm{~K} \mathrm{~K}_{2} \mathrm{O} / \mathrm{ha}$, $\mathrm{T}_{4}$ : Farmers' practice 
As per Student $\mathrm{T}$ test estimates derived through statistical analysis, there was significant correlation amongst these five variables. Correlation coefficient between rice yield and WSK, ExK, AvK and NEK was $0.640,0.824,0.819$ and 0.825 , respectively as given in Table 5.

Kaskar et al., (2001) found that there was highly significant positive relationship amongst different fractions of $\mathrm{K}$ in soil indicating existence of equilibrium between these forms. Similar results with different soil type were also reported by several researchers (Chand and Swami, 2000; Kaskar et al., 2001; Sharma et al., 2009) Any management practice needs to be evaluated in terms of economics and $\mathrm{B}: \mathrm{C}$ ratio. In this experiment, it was worked out by taking into account the market value of rice production inputs and produce of Pusa Basmati 1 rice. It was evident from data that highest gross return (Rs 104146/ha) and net profit (Rs 64462/ha) were recorded with $\mathrm{T}_{3}\left(96 \mathrm{~kg} \mathrm{~K}_{2} \mathrm{O} / \mathrm{ha}\right.$ or $\mathrm{K}_{80}$ ). However, the $\mathrm{B}: \mathrm{C}$ ratio was found maximum (2.72 per rupee invested) with $\mathrm{T}_{1}(0 \mathrm{~kg}$ $\mathrm{K}_{2} \mathrm{O} / \mathrm{ha}\left(\mathrm{K}_{0}\right)$ as given in Table 6 .

It may be concluded from the present study that Pusa Basmati-1 significantly responded to the use of different doses of potassium, along with recommended doses of other fertilizers $\mathrm{N}, \mathrm{P}, \mathrm{Zn}$ in increasing yield, yield contributing characters, nutrient content. The application of $80 \mathrm{~kg} \mathrm{~K} / \mathrm{ha}$ along with $\mathrm{N}$ (120 $\mathrm{kg})$ and $\mathrm{P}\left(60 \mathrm{~kg} \mathrm{P}_{2} \mathrm{O}_{5}\right)$ gave significantly highest grain yield of rice cv Pusa Basmati 1 in Vertisols of Madhya Pradesh. However, 40 $\mathrm{kg} \mathrm{K}$ dose has yielded stastically at par yield. Thus, yield attributes and yield of rice (Pusa Basmati-1) were highest with $80 \mathrm{~kg} \mathrm{~K} / \mathrm{ha}$ followed by $40 \mathrm{~kg} \mathrm{~K} / \mathrm{ha}$. Thus, even though Vertisols are medium to high in $\mathrm{K}$ status these soils are responding to the graded doses of $\mathrm{K}$. The highest net profit as well as $\mathrm{B}: \mathrm{C}$ ratio was recorded with the application of $80 \mathrm{~kg} \mathrm{~K} / \mathrm{ha}$ followed by $40 \mathrm{~kg} \mathrm{~K} / \mathrm{ha}$.

\section{References}

Bahmariar, M.A., Ranjbar, G.A. and Ahamafian, S.H. (2007) Effect of $\mathrm{N}$ and $\mathrm{K}$ application on agronomic characteristics of two Iranian and landrace rice (Oryza sativa L.) cultivars, Pakistan Journal Biological Science 10(6) 880-886.

Biswas, J.C., Ahmed, M.T., Islam, M.R. (2001) Lodging vs. non-lodging in BRRI dhan. Bangladesh Journal of Training Development 14(1\&2) 107113.

Chand, Subhash and Swami, B.N. (2000) Different forms of potassium in some important soils of Bharatpur district of Rajasthan. J. of Potassium Res. 16: 59 61.

Chandrasekhararao, C. and Krishnamurthy, V.(2007) Quantity-intensity relationship of potassium in flue-cured virginia tobacco soils of Khammam district, Andhra Pradesh. Journal of the Indian Society Soil Science 55 (2): 212-215.

Kaliha U, Oiha J, Talukdar M.C (1995) Effect of levels and time of potassium application on yield and yield attributes of upland rice. Assam (India) Journal of Potassium Research 11(2) 203-206.

Kaskar, D. R., Salvi, V. G., Mayekar, B. S. and Dabke, D. J. (2001) Forms of potassium, their interrelationship and relationship with other soil properties of Inceptisols of west coast of Maharashtra. J. of Potassium Res. 17: $23-27$.

Krishnappa M, Gowda KN, Shankarnarayan V, Maharudrappa K, Khan M.M. (2006) Effect of graded levels and split application of potassium on its availability and yield of rice, Journal of Potassium Research 6(4) 156-161.

Majumdar Kaushik, Anil Kumar, Vishal Shahi, T Satyanarayan, M.L. Jat, Dalip Kumar, Mirasol Pampolino, Naveen Gupta, Vinay Singh, B.S. Dwivedi, 
M.C. Meena, V.K. Singh, B.R. Kamboj, H.S. Sidhu and Adrian Johnston (2012). Economics of potassium fertilizer application in rice, wheat, and maize grown in the Indo-Gangetic plains. Indian Journal Fertilizer 8(5): 44-53.

Mathad, K.K.V., Bandi, A.G. and Umesh, A. (2002) Influence of tillage, drainage practices and potassium levels on yield and quality of rice under tanked conditions. Research on Crops 3 (3): 488-49.

Meena, S.L., Singh, S., and Shivay, Y.S. (2003) Response of rice (Oryza sativa L.) to $\mathrm{N}$ and $\mathrm{K}$ application in sandy clay loam soils. Indian Journal of Agricultural Science 73 (1) 8-11.1.

Mitra GN, Sahoo D, Rout KK 2001: Effect of $\mathrm{N}-\mathrm{K}$ interaction on yield, nutrient uptake and grain quality of ricegroundnut cropping sequence in the alluvial soils of Orissa, Journal of Potassium Research 17 (1-4): 71-78.

Mukherjee, D. and Sen, A. (2005) Influence of rice husk and fertility levels on the nutrient content of rice (Oryza sativa). Department of Agronomy, Institution of Agricultural Science, Varansi, India. Agricultural Science, Digest. 25(2) 151152.

Padole, V.R. and Mahajan, S.B. (2003) Status and release behavior of potassium in some swell- shrink soils of Vidarbha, Maharashtra. J. Maharashtra Agric. Univ. 28:3-7

Razzaque, A.H.M., Ali, M.I., Habibullah, A.K.M. (1990) Response of boro rice to potassium application in two soil of Bangladesh. Bangladesh Journal of Soil Science 21(1) 26-29.

Saha, P.K., Ishaque, M., Saleque,, M.A., Miah, A.M., Panaullah,, G.M., Bhuiyan, N.I. (2007) Long-term integrated nutrient management for rice- based cropping pattern, effect on growth, yield, nutrient uptake, nutrient balance sheet and soil fertility. Soil Science Plant Anurantoal. 38 (5/6) 579-610.

Sahu Lekh Ram, Pandey N, Chandu Lal, Navrang Sandeep and Tiwari Bajaj Sakshi. (2015) Effect of Reference of different agrochemicals in conjunction with different source of nutrient supply on growth characters, yield enhancement and soil fertility. Annals of Plant and Soil Research 17 : 87-90.

Sharma Upinder and Subehia, S.K. (2014) Effect of long-term integrated nutrient management on rice (Oryza sativa L.) wheat (Triticum aestivum L.) productivity and soil properties in North-Western Himalaya. Journal of the Indian Society of Soil Science 62: 248-254.

Sharma, Anil, Jalali, V.K., Arya, Vivek M, and Rai, Pradeep (2009) Distribution of various forms of potassium in soils representing intermediate zone of Jammu region. Journal of the Indian Society Soil Science 57(2):205-208.

Singh, Devendra, Vijay Singh and Ravendra Singh (1999) Potassium status of soils and response of rice to applied potassium. J. Potassium. Res. 15(1-4): 83-87.

Singh, J. and Singh, C.M. (2000) Effect of potassium application in rice (Oryza sativa L.)- wheat (Triticum aestivum) cropping system. Indian Journal of Agronomy 45 (1) 12-20.

Singh, Muneshwar, and Wanjari, R.H. (2013) Measures to sustain and restore declined productivity in Alfisols under Long Term Fertilizer Experiments. Indian J. Fertilisers 9(2): 24-32.

Singh, R.K., Swami, B.N. and Dashora, P.K. (2001) Studies on K release characteristics of Masitwali soil series of Rajasthan. National Seminar on Developments in Soil Science, Indian Soc. Soil Sci., 66th Annual Convention: $30^{\text {th }}$ Oct. $-2^{\text {nd }}$ Nov. 2001, New Delhi. 
Srinivasarao, Ch., Swarup, A., Subba Rao, A. and Rajagopal, V. (1999) Kinetics of Non-exchangeable potassium release from a Tropaquept as influenced by long-term cropping, fertilization and manuring. Australian Journal of Soil Research 37: 317-328.
Tabar, S.Y. (2012) Effect of Nitrogen and Phosphorus Fertilizer on Growth and Yield Rice (Oryza sativa L). International journal of Agronomy and Plant Production 3 (12): 579-584, 2012.

\section{How to cite this article:}

Vinod Birla, M. D. Vyas, Megha Dubey, Usha Waskle and Basant Kumar Mandre. 2020. Effect of Different Doses of Potassium on Growth, Yield Attributing Characters of Rice in Vertisol Soil of Madhya Pradesh, India. Int.J.Curr.Microbiol.App.Sci. 9(03): 2629-2642. doi: https://doi.org/10.20546/ijcmas.2020.903.301 